Correspondentie.

\title{
VOLKSVOORLEZINGEN.
}

\section{Aan de Economist}

In uw No. van Nov. 1872 komt een belangrijk artikel voor van F. N. uit Rotterdam, betiteld Volksvoorlezingen. Sinds jaren heb 1k mijne krachten daaraan toegew!jd, geen wonder dus, dat het artikel zeer mijne aandacht trok. Hoe beter nu een stuk geschreven is, des te meer kan het invloed uitoefenen, en daarom vooral schunt het zaak, op te komen tegen beschonwingen, welke, naar eigen ervaring, minder just zijn.

Ik ben het in vele zaken volkomen eens met den geeerden schrijver, ook daarin, dat het spreken voor het rolk oneindig moeijelijker is dan voor een wetenschappelijk publiek; de volksspreker moet zijn onderwerp niet minder, doch meer machtıg zıjn dan hıj, die alleen voor ontwikkelden optreedt, omdat hy uit den aard der zaak verplicht is tot eene zeer duidelyke, bevattelijke voorstelling. En leert het de ondervinding nuet ook in het dagelijksch leven, zoodanige voorstelling kan niet geleverd worden dan door semand, het onderwelp volkomen machtig en veelzijdig ontwikkeld. Maar wie moet de geschiktheid en bekwamheid voor lederen werkkring beoordeelen? zeker niet de persoon, die werkdadig optreedt

Er worden wel eens voordrachten gehouden, warin de sprekers zulke afdoende en hoogst aanschouwelijke bewijzen geven van de grootste onkunde, dat het minst ontwikkeld deel van het publiek zich zit te verkneuteren wegens de verregaande eigenliefde des splekers, die als toejuiching opvat, wat als spot moet gelden. $B_{1}$ dezen spreker, $F \mathrm{~N}$, vindt het omgekeerde plaats. $H_{\mathbf{l j}}$ sprak driemalen, de eerste keer was de zaal halfool, de 2e keer goedgevuld, de $3 \mathrm{e}$ keer stompool, terwul zich nog personen moesten verwijderen, voor welke geen plaats was. Uit dat medegedeelde moet men opmaken, dat F. N. voor die taak belekend is, en zijn het geene enkele aardigheidjes geweest, wat men van hem, te oordeelen naar zyn artikel, niet kan verwachten, adidigheidjes welke men alleen als toespijs en nooit te overvloedig mag geven, dan is het zeker dat $\mathrm{F} \mathrm{N}$. in dit zoo groot volksbelang zich zeer verdienstelijk zou kunnen maken Is nu de bescheidenheid en nederigheid van F. N. net zoo af te keuren, als de verregaande eigenliefde van die sprekers, op welke ik doelde, hier komt het oordeel het publıek toe, de volkswaan van den dag daargelaten, de volkswaan, die als nevel wordt weggevaagd door de liefelıke stralen der zon, - houd ik het overeenkonstig de wijsbegeerte van den bekenden Tyl, op den duur althans, met het gevoelen der massa. 
F. N. wil de schuld van de weinige ontwikkeling onder den werkman voor een groot deel zoeken in het onderwijs; hoczeer ik met zijne grieven en de oorzaken daarvan instem, en er zelfs nog wel wil bijvoegen, dat het onderwijs voor hen wier leertyd begint en eindigt met de lagere school, inzonderheid voor de armenschool, mij toeschijnt te veel te omvatten en te weinig voorbereidend te wezen voor het praktische leven, wil ik toch wel het bijrocgljk naamwoord schrappen; ik heb toch nog grooter bezwaar tegen het ongeregeld bezoek en het te vroeg verlaten der school, zonder dat later onderhouden wordt de verkregen kennis, welke te eerder vervliegt, naar mate zij minder volledig is. Op grootere plaatsen bestaat voor wie het ernstig zoeken wil, later nog wel eenige gelegenherd om wat op te doen; in kleinere gemeenten is dat minder, ten platten lande zelden het geval. Daar zul men dus op onze vereenigingen onder de toehoorders vinden sommigen, die geheel verstoken bleven van lager onderwijs, meerderen, die het slechts zeer gebrekkig genoten. Voor die soort van menschen is het spreken ongetwijfeld nog veel moeielyker dan voor zoodanig gehoor, als voor 't welk vermoedelijk $F$. N. driemalen optrad. Zijne ondervinding, zou lk haast zeggen, is niet groot, hy schijnt alleen af te gaan op plaatsen als Rotterdam, waar de kennis en ontwikkeling der hoorders grooter en waar ook meer middelen zijn om in de kosten te voorzien en een en ander leidt hem tot eenzıjdgheid. Ik schrif het daaraan toe, dat hij de wenschelijkheid der afwisseling (die ook wel te Rotterdam nuttig zal zijn) niet inziet en op de betaling der sprekers aandringt. Vele vereenigingen voorzien nu al niet dan met de grootste moeite in de onveımıdelyke uitgaven en de centrale kas is ook hulpbehoevend. Het weldadig Nederland heeft voor zoodanige inwendige zending in zun midden geen geld over. Wil soms echter $F$. $\mathrm{N}$ de stelling opwerpen, dat in den regel de beoefenaar van een vak meer vertrouwen verdient dan de dilettant, ik zal, (al behoort de tyd tot het verledene, dat wij iemand schatten naar zign gl aad of titel), dat niet tegenspreken, en toch zun er hier behalve kennıs meer factoren in het spel, welke de quaestie beheerschen. Om iets te "noemen, wij hebben hier ook noodig de koesterende vlam der liefde, welke in den regel meer zal gevonden worden bij den dilettant dan bij hem die optreedt om er zijn dagelyjksch brood mee te verdienen.

F. N. schijnt te wenschen een bepaalden oursus; ik reken die voor ons publiek, zelfs voor dat in de grootere plaatsen, geheel ongeschikt. De proeven met raste lectoren genomen, - lectoren op welker bekwaamen geschiktheid ik niets wensch af te dingen, - moet hier in den tijd ons publiek hebben verjaagd. Afwisseling, in alles zoo wenschelyk, is in deze zaak len eene male onontheetlyk; 't kan en 't zal wel zoo wezen, overeenkomstig het leerstuk van de verdeeling van den arbeid, dat door die verdeelng ook hier, het geleverde grondiger en degelıgker zou 
worden. Maar als deze meerdere grondigheid, hoe wenschelyk ook op zich zelf, verveling moest met zich voeren, zou zij allernadeeligst werken op de volksvoorlezingen en tejduur gekocht zijn.

Ik heb ml natuurlijk ook dikwijls afgerraagd, en met velen, zoo op de beide congressen aan dat belang gewijd als elders, beraadslaagd, waartoe eigenlijk de volksvoordrachten moeten strekken en hoe wij moeten werken? En dan geloof ik, geheel in strijd met F. N. (*), dat wij niet tot ons publiek moeten afdalen, wat sonmigen wel zoo zullen begrijpen, het is de kruimkens toewerpen, die van onze tafel vallen; weder anderen, dat het geoorloofd, ja wenschelijk zou zijn ons plat, zoo zelfs niet gemeen uit te drukken, om begrepen te worden; neen dat wij zoo moeten handelen en spreken, dat het volk beseft, dat wij ons beschouwen als wezens van gelijke natuur en niets meer, die alleen slechts wat meer kennis en ontwrkkeling boven de hoorders vooruit hebben. Men dale dus niet af tot de hoorders, daar is niemand mee gebaat en de spreker gaat in zijne laffe en zoutelooze aardigheden daardoor te gronde, maar men heffe het gehoor langzamerhand en van lieverlede, naarmate van zijne toenemende ontwikkeling, tot zich zelven op. Men worde niet moedeloos onder dien langzamen tred, waardoor dikwils eerst volgende geslachten zullen oogsten wat wij zaaien, die langzame tred is een waarborg tegen reactie, een der onmisbare vereischten voor het ongestoord veldwinnen van de beschaving en den waren vooruitgang; dat staat daarbij vast, dat onze voordrachten, de uitnemendste zelfs onder haar noch kunnen vervangen, noch zelfs kunnen aanvullen ongenoegzaam lager onderwijs.

Ik meen het mij zelven wat meer gemakkelijk te kunnen maken en tevens mijne bedoelingen nader te doen kennen, door hier eenige zinsneden op te nemen, uit de toespraak, waarmede ik de voordruchter voor 't loopend saizoen hier ter plaatse opende.

"Afwisseling van sprekers en onderwerpen is ongetwijfeld minder dienst„baar tot het vermeerderen der eigenlijk gezegde kennis, toch komt „zij mij hoogst nuttig voor tot het opwekken en gaande houden uwer „belangstelling; met volkomen recht zegt een fransch spreekwoord, elk „stelsel is goed, behalve zulk een, dat verveling opwekt. Waar nu de "oefening op school in de 1200 of 1300 leeruren 's jaars geene goede "vruchten afwerpt, zonder nadenken en zelfoefening der leerlingen, zal „er zeker nog wel ninder te wachten zijn van de weinige uren, welke „wij hier met elkander doorbrengen, met een waarschijnllyk hier nog wel „minder geregeld opkomen en onder voor ons zoo veel minder gunstige

(*) Naar onze meeuing is bet gevoelen van corr hier geenszins in strijd met F. N. Die wil ook geen afdalıng des sprekere; hy waarschuwt nadrukkelyk tegen platheid, en verlangt oordeelkundige ophetling der hoorders.

[RED ] 
„omstandigbeden Maar kunnen nu de zoogen rolksvoordrachten zeer zeker "uwe kennis niet belangrijk doen vermeerderen, allerminst het gemis „aan behoorlyk onderwijs in uwe jeugd vervangen of aanvullen, ik voor „nij ben tevreden en acht ons doel volkomen bereikt, wanneer wij u „over 't meerendeel der hier behandelde onderwerpen meer juiste en „heldere denkbeelden verschaffen, de overtuiging inboezemen of de be"staande versterken mochten, dat er oneindig veel in de wereld te koop „is en $u$ dus, zonder dat $w j$ wenschen, dat gy eene vlucht neemt boven „de kracht uwer wieken, nopen tot voortdurend onderzoek, dat wiy u "trachten te vormen tot denkende en zelfstandige wezens."

Geeft $\mathrm{F}$ N. zeker menigen nuttigen wenk, dien ik van harte onderschrijf, ik roep uwe hulp in Heer Redacteur, om, waar $\mathrm{k}$ in meening met hem verschil, ook mijne denkbeelden mede te deelen over een allergewichtigst belang dat een zoo grooten invloed kan oefenen op de ontwikkeling van ons volk.

Hoorn, 7 Dec. 1872.

A. VAN ECK.

Nederlandsche Bank. (In milloentallen guldens.)

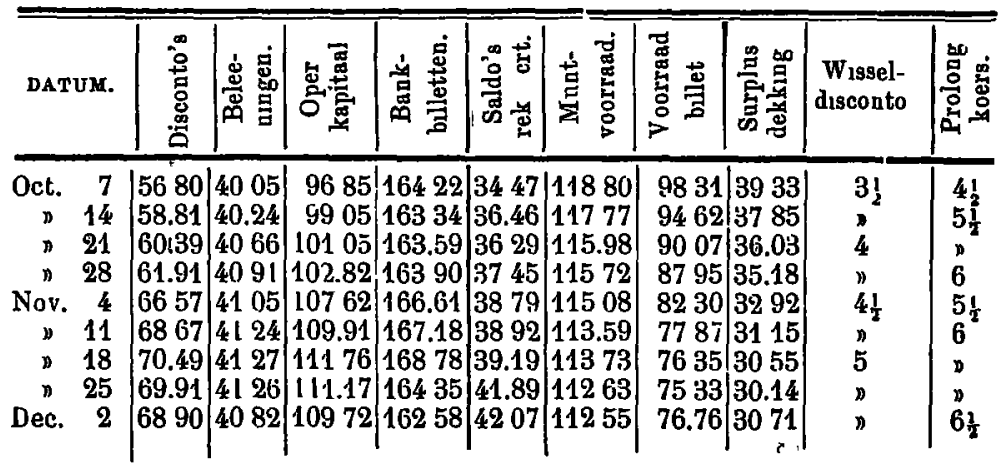

Wisselkoersen te Amsterdam.

\begin{tabular}{|c|c|c|c|c|}
\hline DATUM. & kort & $\begin{array}{c}\text { kort } \\
\text { Parpls. }\end{array}$ & $\begin{array}{c}\text { kort } \\
\text { Hamburo }\end{array}$ & $\begin{array}{c}\text { Frankfort. } \\
6 / w \text {. }\end{array}$ \\
\hline $\begin{array}{rr}\text { Oct. } & 7 \\
\# & 14 \\
& 21 \\
& 28 \\
\text { Nov. } & 4 \\
n & 11 \\
n & 18 \\
\text { Dec. } & 25 \\
\text { Dec } & 2\end{array}$ & $\begin{array}{l}1206 \\
1208 \\
1207 \frac{1}{2} \\
1210 \\
12.04 ! \\
12.08 \frac{1}{2} \\
1216 \\
1214 \\
12.10\end{array}$ & 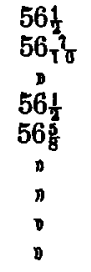 & $\begin{array}{c}353 \\
n \\
n \\
n \\
35 \frac{1}{2} \\
35_{16}^{3} \\
0 \\
355_{1}^{\prime} \\
35 \frac{1}{4}\end{array}$ & $\begin{array}{c}1003 \\
n \\
n \\
0 \\
n \\
100 \\
n \\
n\end{array}$ \\
\hline
\end{tabular}




\section{OPGAVE van de hoogate en ladgste Coursen van de onderstaande}

Effecten aan de beurs te Amsterdam.

\begin{tabular}{|c|c|c|c|c|c|c|c|c|}
\hline \multirow[b]{3}{*}{ Vedorland Nat W Sch } & \multicolumn{2}{|c|}{$\begin{array}{c}\text { Volle jaar } \\
1871 .\end{array}$} & \multicolumn{2}{|c|}{ SEPT. 1872.} & \multicolumn{2}{|c|}{ Ост. 1872.} & \multicolumn{2}{|c|}{ Nov. 1872.} \\
\hline & $\mid \begin{array}{l}\text { Laggto } \\
\text { oours. }\end{array}$ & $\begin{array}{l}\text { Hoogate } \\
\text { Seours. } \\
\end{array}$ & $\begin{array}{l}\text { Laagete } \\
\text { eourta. }\end{array}$ & $\begin{array}{l}\text { Hoogsto } \\
\text { cours. }\end{array}$ & $\begin{array}{l}\text { Langute } \\
\text { ooure. }\end{array}$ & $\begin{array}{l}\text { Hoggsto } \\
\text { oours. }\end{array}$ & & \\
\hline & $51 \frac{7}{8}$ & $58 \frac{1}{8}$ & $54 \frac{5}{R}$ & $5+\frac{8}{8}$ & 543 & $55 \frac{1}{16}$ & $54 \frac{1}{8}$ & $55 \frac{5}{8}$ \\
\hline " $" \times \mathbf{3}^{2}$ & $61^{8}$ & $66 \frac{1}{4}$ & & & & & & \\
\hline 4 & $81 \frac{3}{4}$ & $88 \frac{1}{2}$ & 87 & $88 \frac{1}{4}$ & & $88_{10}^{3}$ & $85_{8}^{2}$ & $87 \frac{1}{4}$ \\
\hline Spange. Oblig. 3 & & $\overline{1}$ & $1-$ & & -5 & $\overline{30}$ & - & - \\
\hline * Buitenl. 18673 & 29 & $34 !$ & j2s & 31 & $\left\{\begin{array}{l}29 \frac{5}{8} \\
\end{array}\right.$ & $30 \frac{5}{1 \pi}$ & $29 \frac{1}{4}$ & 30,5 \\
\hline $\begin{array}{cc}\text { Bimnenl. Sch. } & 3 \\
\text { ortugal. Oblig. 1853 } & 3\end{array}$ & $\begin{array}{l}25 \\
31 \frac{1}{2}\end{array}$ & $\begin{array}{l}29 r^{5} \\
37\end{array}$ & $1-25 \frac{1}{2}$ & $26+$ & $125 \frac{7}{6}$ & 20 & $25, \frac{8}{18}$ & $25 \frac{1}{8}$ \\
\hline$n \quad 1856 / 673$ & $30 \frac{2}{8}$ & $37 \frac{1}{4}$ & $40 \frac{7}{8}$ & $41+3$ & \}405 & $41_{5}^{3}$ & $40, y$ & $41 \frac{1}{6}$ \\
\hline Rus/.Ob. Hope \& C. 178 5 & $92 \frac{3}{4}$ & $98^{7}$ & 98 & $99 \frac{1}{8}^{\circ}$ & $98 \frac{3}{2}$ & $993^{\circ}$ & $97 \frac{1}{8}$ & $98 \frac{3}{4}$ \\
\hline - Stiegl.5eser. 18545 & $62 \frac{3}{4}$ & 70 & $73 \frac{3}{4}$ & $74 \frac{3}{8}$ & $73_{\frac{1}{2}}^{2}$ & $74 \frac{1}{2}$ & 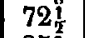 & 73 \\
\hline $\begin{array}{l}\text { bes } \\
\text { Hope C. à f1C }\end{array}$ & $\begin{array}{l}75 \\
893\end{array}$ & $\begin{array}{l}83 \frac{5}{4} \\
967\end{array}$ & $\begin{array}{l}85 \frac{1}{2} \\
97 !\end{array}$ & $\begin{array}{l}86 \frac{?}{8} \\
981\end{array}$ & $85 \frac{1}{2}$ & $\begin{array}{l}86 \frac{1}{2} \\
98 \frac{1}{2}\end{array}$ & $\begin{array}{l}857^{7} \\
97\end{array}$ & $\begin{array}{l}86 \frac{1}{4} \\
97 \frac{1}{7}\end{array}$ \\
\hline Cert. insehr. & $41 \frac{3}{8}$ & $45 \frac{1}{2}$ & $48 \frac{3}{4}$ & $\begin{array}{l}78 \frac{1}{2} \\
48 \frac{2}{8}\end{array}$ & 48 & $48 \frac{\pi}{8}$ & 48 & $48 \frac{1}{8}$ \\
\hline Oostenr. Metall & & & & & & & & \\
\hline (uit de conv. & $44 r^{7}$ & $51 \frac{3}{4}$ & $58 \% \pi$ & $60 \frac{1}{2}$ & $58 \frac{3}{4}$ & 61 & & \\
\hline Veen.Loten fl.250 1839 & $571^{51 \frac{1}{4}}$ & $735 \frac{1}{4}$ & $945^{7 / 6}$ & $6^{655^{8}}$ & $\begin{array}{l}63 \frac{7}{8} \\
938\end{array}$ & 643 & $\begin{array}{l}68 \mathrm{r} \\
900\end{array}$ & \\
\hline fl. 25018544 & 215 & 247 & 254 & 201 & S & 262 & 262 & 275 \\
\hline$n \quad 11.10$ & 150 & 196 & & 208 & & 203 & 02 & 203 \\
\hline in. 5 & |441 & 526 & 566 & 86 & & 79 & & 74 \\
\hline a. 1001864 & $107 \frac{1}{4}$ & $143 \frac{3}{3}$ & 154 & 160 & 156 & 159 & 109 & \\
\hline $\begin{array}{l}\text { 7urkije. Oblig. alg. sch. } 5 \\
\text { Amer. Obl.V.-S. } 18745\end{array}$ & $40 i$ & $48 \frac{3}{11}$ & 503 & $52 \frac{1}{2}$ & $50 \frac{7}{8}$ & $523^{3}$ & $51 y^{1}$ & $\begin{array}{l}52 ! \\
95 !\end{array}$ \\
\hline "-5. 18746 & $\begin{array}{l}92 \\
94 !\end{array}$ & $\begin{array}{l}96 \\
98 \frac{7}{8}\end{array}$ & $\begin{array}{l}95 \\
97\end{array}$ & $\begin{array}{l}95 \frac{1}{2} \\
98 !\end{array}$ & $\begin{array}{l}95 \\
97 \frac{3}{4}\end{array}$ & $98 \frac{3}{2}$ & $97 \frac{3}{8}$ & $98 \frac{1}{2}$ \\
\hline$\therefore$ 은 18856 & $93 \frac{7}{8}$ & $99 \frac{8}{8}$ & $98_{\frac{1}{2}}^{10}$ & $99 \frac{1}{2}$ & $98+\frac{4}{10}$ & $99 \frac{5}{8}$ & $98^{8}$ & 99 \\
\hline Brazilie.Obl. leen. 18655 & $89 \frac{1}{4}$ & $94 \frac{5}{R}$ & 9 & $96 \frac{2}{8}$ & $93 \frac{3}{4}^{\circ}$ & $94 \frac{3}{5}$ & $94 \frac{1}{2}$ & \\
\hline Mexico D 18513 & $12 \frac{1}{4}$ & $14 \frac{1}{2}$ & 143 & $15 \frac{1}{4}$ & $14 \frac{3}{4}$ & $16 \frac{1}{2}$ & $15 \frac{1}{1}$ & $15 \frac{3}{8}$ \\
\hline 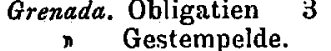 & $\begin{array}{l}36: 4 \\
17+\frac{3}{3}\end{array}$ & $\begin{array}{l}39 \frac{3}{4} \\
24 \frac{7}{8}\end{array}$ & $\begin{array}{l}38 \\
21 \frac{1}{2}\end{array}$ & $\begin{array}{l}38 \\
23\end{array}$ & $\begin{array}{l}38 \\
21 \frac{3}{4}\end{array}$ & $\begin{array}{l}38 \\
235\end{array}$ & $\begin{array}{l}38 \\
21 \\
4\end{array}$ & $\begin{array}{l}381 \\
23 \\
3\end{array}$ \\
\hline Venezuela. Obligatien $\mathbf{3}$ & $7 \frac{5}{1 \pi}$ & $9 \frac{1}{4}$ & $10 \frac{1}{\mathrm{E}}$ & $10 \frac{3}{4}$ & $9 \frac{7}{8}$ & $10 \frac{1}{4}$ & $9_{T^{5}}^{\mathbf{5}^{2}}$ & $10 \mathrm{rg}$ \\
\hline SPOORWEGEN EN MAATSCH. & & & & & & & & \\
\hline Aandeelen I & $\mid 280$ & 300 & 29 & 29 & $4 \frac{1}{4}$ & 295 & & 0 \\
\hline $\mathrm{Nec}$ & $\mid 117 \div$ & 136 & $136 t$ & $138 \frac{3}{7}$ & $\frac{3}{4}$ & 373 & 13 & 137 \\
\hline \# Holl & 103 & 114 & $113 \frac{1}{2}$ & $114 \frac{1}{2}$ & $110_{2}^{\frac{1}{2}}$ & 112 & 110 & 111 \\
\hline Obl. Holland & $82 \frac{1}{2}$ & $87 \frac{1}{2}$ & $\overline{0}$ & $a-$ & & $83 \frac{1}{4}$ & & $83 !$ \\
\hline Aand & 263 & 306 & 296 & 300 & (2) & 298 & 12 & 29 \\
\hline 84 & 107 & 111 & 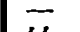 & $\overline{-1}$ & & $110 \frac{1}{4}$ & 110 & $110 \frac{1}{2}$ \\
\hline A and. Ned. In & 22 & $52 \frac{1}{2}$ & 4 & $\begin{array}{c}45 \\
1183\end{array}$ & $\begin{array}{r}44 ! \\
112^{2}\end{array}$ & $\begin{array}{r}46 \\
118\end{array}$ & & $\begin{array}{r}493 \\
117 !\end{array}$ \\
\hline $\begin{array}{l}\text { Maats. Expl. } \\
\text { n Ned. Ind. Ha }\end{array}$ & $\begin{array}{l}89 \\
60\end{array}$ & $\begin{array}{r}126 \\
71\end{array}$ & $\begin{array}{r}116 \frac{1}{2} \\
64 \frac{1}{2}\end{array}$ & $\begin{array}{c}118 \frac{3}{4} \\
73\end{array}$ & 7 & $\begin{array}{r}118 \\
74 \frac{1}{2}\end{array}$ & $\left|\begin{array}{r}112 \frac{1}{2} \\
72 \frac{1}{2}\end{array}\right|$ & 75 \\
\hline Pandbr.Nat. Hyp & 95 & 98 & 98 & 98 & $97 \frac{3}{4}$ & 98 & - & - \\
\hline 1 & $81 \frac{1}{4}$ & 妾 & & $88 \frac{1}{2}$ & & 881 & $87 ?$ & \\
\hline Aand. N & 99 & 40 & $31 \frac{1}{2}$ & 34 & & & 31 & 3 \\
\hline Oblig. C & $77>3$ & 104 & $94 \frac{1}{2}$ & 98 & $95 \frac{1}{2}$ & $\sqrt[9]{\frac{1}{2}}$ & 0 & 9 \\
\hline Aand. 00 & 680 & 83 & $958-2-r-2$ & 970 & 955 & 1100 & 1070 & 1110 \\
\hline "Rus & $210 \frac{i}{2}$ & 226 & $227 \frac{1}{2}$ & 229 & 9 & 230 & & \\
\hline 00010 & & 218 & & $221 \frac{1}{4}$ & $218 \frac{3}{4}$ & 222 & 220 & 2221 \\
\hline Obl. sp.f1000(Jel. Or.) 5 & $81 \frac{3}{4}$ & $91 \frac{1}{8}$ & $92 \frac{1}{2}$ & 94 & 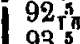 & $93 \frac{1}{4}$ & 91 i & $93 !$ \\
\hline o f 10 & $\begin{array}{l}82 \\
81\end{array}$ & $\begin{array}{l}921 \frac{1}{4} \\
91\end{array}$ & $\begin{array}{l}928 \\
931\end{array}$ & $\begin{array}{l}94 \\
94\end{array}$ & $\begin{array}{l}95 r^{8} \\
92 \frac{3}{8}\end{array}$ & $\begin{array}{l}94 \\
935\end{array}$ & $\begin{array}{l}92 \frac{1}{2} \\
921\end{array}$ & $94 \mathrm{~g}$ \\
\hline 190 & & & & & & & & \\
\hline ow) 5 & 81 & 89 & $90 \frac{3}{4}$ & 925 & $90 \frac{1}{2}$ & 92 & $91 \frac{3}{4}$ & 92 \\
\hline Gertific. I & $\mid 114 \frac{1}{2}$ & 1223 & $114 \frac{3}{3}$ & $116^{\circ}$ & $109^{\circ}$ & $115 !$ & $106 \frac{1}{2}$ & $114 \frac{1}{2}$ \\
\hline bl. St. Paul Pac. 2 e sect & $63 \frac{1}{2}$ & 72 & & 76 & 6. & $72 \frac{3}{8}$ & $63 \frac{1}{2}$ & $67+$ \\
\hline Be & 3 & 4 & & 6 & & $\begin{array}{l}5 \\
6\end{array}$ & & \\
\hline Disconto & $\mathbf{3}$ & & $2 \frac{1}{2}$ & 3 & $\sigma_{\frac{1}{2}}$ & * & 4 & \\
\hline
\end{tabular}




\section{ECONOMISCHE NALEZINGEN EN BERIGTEN.}

- Het Jaarboekje voor 1872, der Vereeniging voor de Statistiek is dezer dagen verschenen.

Deze jaargang, de $24 \mathrm{e}$ van de nuttige serie, in de eerste plaats aan de onvermoeide pogingen van den heer de Bosch Kemper te danken, is uitgebreider dan gewoonlijk (ruim 500 bladz.) en belangrık van inhoud.

Na de gewone statistische mededeelingen in de eerste Afdeelingen bevat de IIIe Afd. de navolgende opstellen over gemengde onderwerpen.

Meteorologre. Statistiek van de weêrsgesteldheid te Utrecht in 1871, door Dr. Buys Ballot.

Bevolknkg. Loop der bevolking in Nederland in 1870, in vergelijking met 1860-1868, door Mr. M. M. von Baumhauer. - Bevolkıng van Nederland, volgens de tienjarige volkstelling, 30 Nov. 1869, I. Bevolking der Provincien. - II. Aantal gemeenten. - III. Bevolking der gemeenten in alphabetische orde. - De bevolking van Amsterdam, naar den burgerlijken staat, leeftijd en godsdienst in 1859 en 1869 , en staat der geborenen, overledenen, huwelijken, echtscheidingen enz., gedurende 1852-1871.

Medische statistiek over 1870, door Dr. L. Scheltema Beduin.

Krankzinnigenaestichten. Overzicht der beweging in de Nederlandsche gestichten voor krankzinnigen, gedurende het jaar 1871 , door J. N. R.

OnDERwiJs. De Industrieschool voor vrouwelijke jeugd, opgerigt door de beide Amsterdamsche Afdeelingen der Maatschapplj: Tot nut var ' $t$ Algemeen, door P. van Limmik. - De Ambachtsschool voor de arbeidende klasse te Amsterdam, 1861-1872, door E. S. Witkamp. De Rotterdamsche Ambachtsschool in 1871-72.

INSTELLINGEN VOOR HET VOLK. Arbeiderswoningen 1865-72, door Mr. C. A. Crommelin. - Volksvoordrachten in Nederland, door P. H. Testas.

Provinctale Geldmiddeten. Overzicht van de provinciale ontrangsten en uitgaven in Limburg, over de jaren 1851-1870, door J. P. L. Thiel.

RrJKs-GELDMIDDELEN. De Staatsbegrooting voor 1872 , in vergelyking met de werkelijke ontvangsten en uitgaven in 1870. - De Nederlandsche Staatsschuld in 1872, in vergelijking met 1850 en volgende jaren.

ECON 1872. 
HaNDis, EN SCHEepvaART, BANKWEZEN, FondSENMaRKT ENz. Handel en Scheepvaart in 1870 , in vergelijking met 1846 en volgende jaren, door Dr. H. F. R. Hubrecht. - Verzameling der consulaire berichten en verslagen over nijverheit, handel en scheepvaart, 1869 on 1870 , door P. N. Muller. - De Nederlandsche Handelmaatschappij in 1871. De Nederlandsche Bank. 1 April 1871-31 Maart 1872, door Mr. J. F. B. Baert. - De Fondsenmarkt in 1871, door G. M. Boissevain. - Overzucht van de prijzen der effecten aan de Amsterdamsche bears, gedurende Let jaar 1871. - Wissel- en rentekoersen ter beurze van Amsterdam in 1871. - Vergelykend overzicht van al de in 1862-1871 te Amster dam, in „de Brakke Grond" en in ,het O.-Z. Heeren-Logement” in publieke veiling gebrachte vaste goederen.

BrizfposteriJ. Verslag over de uitkomsten der met $1 \mathrm{Jan} .1871$ ingevoerde postwet van 22 Juli 1870 (St. no. 138), alsmede eenige andere statistieke opgaven betrekkelijk den dienst der postadministratie (met aanteekeningen).

OverzeEsche BEZITTINGEN. De Indische spoorweg, 1867-1871, door J. P. de Bordes.

Butrentand. Een statistiek van de openbare bibliotheken in Zwitserland, door Mr. H. Keer. - Overzicht van de verliezen door den oorlog van 1870-71, aan Frankrijk toegebracht.

- Geneeskundige Armenverzorging, Zieke-bussen. Doeltreffende inrichting der geneeskundzge armenverzorging, zegt een curculaire van den Prov. Geneesk. Inspecteur, dd. Nov. 1872 aan de Gemeentebesturen in Zuid-Holland, is bij het geneeskundig toezigt bij herhalingoverwogen, als een onderwerp van groot gewicht voor alle gemeenten in ons land, en in het bijzonder voor die, waar het beschikbaar zın van goede geneeskundige hulp $\operatorname{van}$ die inricliting af hankelıjk is.

$\mathrm{Bij}$ die overweging werden groote gebreken in den bestaanden toestand erkend.

De nadeelige gevolgen daarvan zullen zich steeds sterker doen gevoelen nu, ten gevolge der wet van 1 Juny 1865 (St. no. 59), de overbevolking van geneeskundigen en de daardoor ontstane onmatige concurrentie allengs zullen plats maken voor een beteren toestand, die de degelijke hulp van bekwame geneeskundigen beter waarborgt, doch wellicht hier en daar gebrek aan hulp zou kunnen doen ontstaan, waar niet de noodige maatregelen worden aangewend om die hulp roor alle klassen der bevolking bereikbaar te maken.

Goede inrichting der geneeskundige armverzorging wordt hiertoe vereischt. Niet alleen omdat zonder laar armen $\in n$ mingegoeden allicht van de noodige hulp zouden kunnen verstoken blijven maar niet minder ook 
omdat het voor vele gemeenten juist van die inrichting af hankelijk is, of aldaar bekwame en degelijke geneeskundigen zich zallen vestigen of gevestigd blijven.

De aanbevolen grondslagen zijn:

' $a$. Beperking der geneeskundige armenverzorging tot de werkelijk armen, met behoorlijk toezicht hierop.

4. Vaste belooning roor den geneeskundige.

c. Vaste belooning voor het gereednaken der geneesmiddelen.

$d$. Levering van de bestanddeelen der geneesmiddelen volgens een tarief van schadeloosstelling.

e. Bevordering zooveel mogelijk van de oprichting van een ziekenfonds voor minvermogenden.

Die grondslagen staan onderling, en met eene deugdelıke inrichting der verloskundige armenpraktijk door vroedvrouwen, in nauw verband. Gezamenlijk vormen zlj een stelsel, dat dán vooral gunstige urtkomstenbelooft, wanneer het in zijn geheel en goed wordt toegepast.

Als hoofdpunt is vooropgesteld dat de geneeskundige armenverzorging door streng toezicht moet beperkt worden tot de werkelık armen. Maar dadeljk valt het in het oog, dat die beperking slechts mogelyk is, wanneer voor een' breeden zoom der bevolking instellingen bestaan, waardoor deze voor eene gernge wekelıksche bijdrage recht kan erldngen op goede geneeskundige hulp in has en geheelen omvang. W $W_{\text {lj }}$ denken hierbıj aan daglooners, fabriekarbeiders, dienstboden, dezulken in een woord, die wel door hunnen arbeld in hunne dagelyksche behoeften kunnen voorzien en in gewone omstandıgheden geen onderstand behoeven, maar dıe in geval van ziekte niet in staat zijn zich de noodige geneeskundige hulp te verschaffeu. Zonder zoodanige instellingen ware het onbillyk, en in de gevolgen zelfs gevaarlijk, om een zoo groot deel der bevolking van de verzorging van gemeentewege uit te sluiten.

Met beperking der geneeskundige armenverzorging tot de werkelijk behoeftigen moet dus noodwendig de oprichting gepaard gaan van zieken. fondsen, die voldoende waarborgen van deugdelıkheid geven en ver. trouwen verdienen. Als een nitstekend voorbeeld tot navolging bij de oprichting van zoodanige ziekenfondsen kan worden gewezen op het „Algemeene Ztekenfonds voor Ansterdam"; eene instelling die, blijkens de ondervinding van meer dan vuf en twintig jaren, in alle opzichten aan hare roeping beantwoordt en die met al hare hoofdbepalingen even goed voor kleine gemeenten als voor groote kan worden ingericht, zooals de ondervinding in kleinere gemeenten reeds lang voldoende heeft bewezen.

Dringend wordt dan ook de oprichting van dergelıke instelling aanberolen in alle gemeenten, waar zij nog niet bestaat.

FoofdBepalingen voor EEN zIEKENFonds. - 1. Het fonds wordt belieerd door of onder toezicht van burgemeester en wethouders. 
2. Tot leden worden alleen aangenomen gezonde personen, die door hụnne maatschappelijken toestand niet in staat zijn, uit eigen middelen op de gewone wijze zich behoorlijk van geneeskundige hulp te voorzien. (Daglooners, fabriekarbeiders, ambachtslieden, dienstboden, enz.)

Een gehuwd man wordt niet zonder zijne vrouw als lid aangenomen, de vrouw niet zonder den man, en het gezin wordt niet zonder de kinderen aangenomen.

Lijders met slepende ziekten of gebreken worden niet aangenomen dan op byzondere voorwaarden, voor elk geval in overleg met den geneeskundige vast te stellen.

3. De wekelijksche bijdrage van ieder lid is 10 centen, voor elk kind beneden de 16 jaren 2 centen.

4. De leden en hunne kinderen genieten roor hunne bijdrage genees-, heel- en verloskundige hulp (de inenting en herinenting der koepokken daaronder begrepen), met uitzondering van instrumenten, pluksel en windsels. Het recht op geneeskundige hulp gaat in nadat men 4 weken, dat op verloskundige hulp nadat men 6 maanden heeft bijgedragen.

5. De geneeskundige genıet voor genees- en heelkundige bulp jaarlijks eene vaste som voor elk lid.

Verloskundige hulp wordt afzonderlyk vergoed. De vroedvrouw (of bij het ontbreken van eene vroedvrouw de geneeskundige) geniet eene vaste vergoeding voor elke verlossing.

De apotheker (waar deze outbreekt de geneeskundige) geniet voor het gereed maken der geneesmiddelen jaarlyks eene vaste som voor elk lid.

De bestanddeelen van de geneesmiddelen worden in rekening gebracht volgens een tarief van schadeloosstelling, vooraf vastgesteld.

Het zetten van bloedznigers en van lavementen wordt afzonderlyk betaald.

Voor de behandeling der kinderen geniet de geneeskundige en roor het gereed maken der geneesmiddelen de apotheker (of de geneeskundige) geen afzonderlijke vergoeding. Voor de aan hen geleverde geneesmiddelen geniet hij schadeloosstelling volgens het vastgestelde tarief.

6. In gewone tijden moet jaarlijks van de inkomsten een gedeelte worden bestemd tot dekking van hoogere uitgaven in ongunstige jaren. (Vooral met het oog op koorts-epidemieen, die groote kosten voor genéesmiddelen veroorzaken, is eene reservekas noodzakelijk)

De administratiekosten van zoodanig fonds - (onkosten voor het ophalen der contributien, voor diuk- en schrijfwerk) - zijn, wanneer het fonds door of van wege burgemeester en wethouders wordt beheerd, gering.

$B_{1 j}$ uitbreiding van zulk een fonds tot geldelijke ondersteuning in ziekte (ziekengelden) en tot uitkeermg bij overlijden is splitsing in afzonderlyke afdeelingen noodig. 
- De Vereeniging tot verbetering der woningen van de arbeidende Klassen to 's Gravenhage, opgerioht in 1854, is meermalen in dit tijdschrift ter sprake gebragt. - Blijkens oirculaire, Dec, 1872 uitgevaardigd, heeft "zij zich voortdurend mogen verheugen in gunstige uitkomsten.

Op kleine schaal angevangen met een kapitaal van f 36,250 , opgenomen tegen een rente van 3 pCt., heeft zij achtereenvolgens f 750,000 tegen 4 pCt., later 100,000 en daarna nog f 162,500 tegen $4 \frac{1}{2}$ pCt. rente, bij leening verkregen en zich bovendien door hypotheek op hare woningen $f 25,000$ verschaft.

Deze gelden strekten uitsluitend: $l_{0}$. tot aankoop van bouwterreinen; $2^{\circ}$. tot aanbouw van woningen; $3^{n}$ tot aankoop en verbetering van slechte woningen.

Thans bezit de vereeniging 398 arbeiders-woningen, waaronder 87 verbeterde en 311 geheel nieuw gebouwde, die behalve enkele winkelhuizen, verhuurd worden tegen $f 1,80$, f $1,75, f 1,60$, f $1,50, f 1,40$, $f 1,10$ en $f \quad 0,75$ per week, naar mate de grootte en meer of min gunstige ligging.

Dat door deze woningen gedeeltelyk althans voldaan wordt aan een sterk sprekende behoefte, blykt reeds annstonds daarut, dat gedurende al de jaren, waarin de Vereeniging werkte, nimmer een enkele woning langer heeft leêg gestaan, dan soms onvermijdelık was, buj veranderıng van huurder; nıet minder uit de weinıge verhuıingen en uit de talrijke candidaten-lijsten voor eventueel openkomende woningen. Wanbetalingen komen dan ook by deze woningen hoogst zelden voor; zelfs geen $\frac{1}{2} \sigma \mathrm{pCt}$. behoeft daarvoor van de inkomsten-rekening te worden afgeschreven.

- Stoompakket-vaarten. De Belgische regering heeft met eene te Londen gevestigde firma eene overeenkomst gesloten, waarbij de laatste zich verbindt eene geregelde stoomvaart tusschen Antwerpen en Valparaiso en Buenos Ayres te onderhouden; in elke der beide lijnen zal maandelijks eene pakketboot van weerszijden afvaren, en de ondernemer zal zich belasten met het vervoer der briefpakketten, waarvoor hem de Belgische regering een minimum ran ontvangst waarborgt van 750,000 francs gedurende de acht eerste jaren en van 700,000 francs gedurende de zeven verdere jaren der concessie. Behalve den duur der reizen bepaalt de overeenkomst dat in die stoomvaartlijnen alleen gebezigd mogen worden stoomschepen van de beste constructie welke met de beste vreemde pakketbooten kunnen wedijveren, en van minstens 4000 tonnen laadruımte voor de lijn op Chili, en van minsten 2000 voor de lijn op Buenos Ayres en Rio Janeiro.

Sedert 1868 exploiteerde dezelfde concessie een geregelde stoomvartdienst tusschen Antwerpen en de havens van Brazilie en de Argentynsche 
republiek, tegen een subsidie van 250,000 franos uit de Belgische schatkist.

$O_{p}$ de N.-Indaische begropting van 1873 komt in art. 54 der uitg. in N.-Indie (in totaal $f 435,000$ ) - behalve het subsidie van $f 332,000$ voor eene pakketvaart in den Ind. Arobipel -, ook thans voor een post: koslen voor eene geregelde stoomgemeenschiap met Australie, f 100,000.

- Internationale Postgemeenschap. De boodschap, welke de President Grant den 2n dezer bij de heropening der zitting van het Congres der Vereenigde Staten indiende, zegt 0 . a. ten dezen aanzien: „Op het vogenblik 'zijn alleen de volgende stoomvaartondernemingen krachtens speciale besluiten van het congres in genot van subsidien voor het overbrengen van postpakketten. De Pacufic Maul Sleumship Company ontrangt een half millioen dollars per jaar voor het vervoer der maandelijkscbe mailpakketten van San Francisco naar China en Japan : op den In Oct. 1873 zal dit subsidie verdubbeld en de maildienst in eene halfmaandelijksche veranderd worden. De Unted Siates and Brazil M. S. Cy. ontvangt $150,000 \mathrm{~d}$. per jaar voor het vervoeren der maandelijksche mailpakketten tusschen New-York en Rio Janeiro, en de California, Oregon and Mexico $S$. Cy. outvangt 75,000 dollars per jaar voor eenen maandelijksclien maildienst tusschen San Francisco en Honolulu (Hawai-eilanden.) De op dit oogenblik uitbetaalde subsidien bedragen dus een eindeyfer van 725,000 dollars per jaar. Uwe welwillende aandacht wordt ingeroepen voor het voorstel van den postmeester-generdal on den maildienst tusschen New.York en Brazilie van een maandelijkschen tot een veertien. daagschen te maken, voor het toekennen van subsidie voor de oprigting van eenen maildienst tusschen San Francisco, Nieuw Zeeland en Australie, en tevens voor zijn voorstel tot de instelling van posikantoor-spaarbanken.

„Op dit oogenblik zijn er niet meer dan drie stoomvaartlijnen welke mailpakketschepen in de vaart hebben en geheel aan Amerikaansche onderdanen toebehooren en onder onze vlag varen. Ik geef u met aandrang in overweging door middel van voordeelige malcontracten het voortdurend bestaan dezer lijnen te willen verzekeren. Wauneer het noodig mogt geacht worden de hulp van regeringswege ook uit te strekken tot stoomvaartondernemingen, welke die rroeger niet genoten, dan zou het, uit een politiek en commercieel oogpunt, overweging verdienen subsidie te verleenen aan eene nationale stoomvaartlijn tusschen Panama en Zuid Amerikaansche havens. Door de oprigting van een zoodanigen dienst zou' een uitgebreide handel, welke zıch thans in handen van andere natien bevindt, aan onze vlag kunneu getrokken worden, ten voordeele zoowel van ons land als van die andere gedeelten van het vasteland van Amerika" 